Stig Thøgersen ${ }^{1 *}$

\title{
China's Symbiotic Narratives of Opening and Globalization
}

\begin{abstract}
The construction of the two symbiotic narratives of "opening" and "globalization" makes it possible for China's leaders to present their policies, and in a wider perspective their rule, as an objective necessity. China's economic growth is represented as a result of the post-1978 Opening policy, while globalization is said to demand a strong and unified state that can defend Chinese interests. The paper discusses the different stages in the construction of these narratives.
\end{abstract}

\section{Introduction}

In December 2008 China celebrated the thirtieth anniversary of its policy of Reform and Opening (gaige kaifang), which was announced at the $3^{\text {rd }}$ plenum of the $11^{\text {th }}$ National Congress of the Chinese Communist Party (CCP) in 1978. In his celebration speech Hu Jintao, China's president and general secretary of the CCP, stated that "China has no chance to develop itself without the world while the world needs China to go ahead with development." At the same time, however, he emphasised that China "will never copy the mode of the Western political institutions," but "firmly uphold the idea that Chinese affairs must be handled by Chinese people in a Chinese way, and oppose any foreign forces to interfere in Chinese domestic affairs” (Hu 2008). ${ }^{2}$

1 I am grateful to Clemens Stubbe Østergaard, Andreas Steen, and two anonymous referees for their comments on the first draft of this paper.

2 The translation is taken from the English language website of the People's Daily [online]. http://english.people.com.cn/90001/90776/90785/6557160.html (accessed 25 January 2009).

* Stig Thøgersen

Department of History and Area Studies, Section af Asian Studies

Aarhus University

Bartholins Allé 16,

DK-8000 Aarhus C

ostst@hum.au.dk

Hermes - Journal of Language and Communication Studies no 43-2009 
Hu here paraphrased the general strategy of the CCP for the last three decades: An ever closer integration into the global capitalist economy and international institutions accompanied not by a transition to liberal democracy - as many in the West had hoped for - but by an adaptation and expansion of the party-state's repertoire of ruling techniques in order to meet the new demands.

In this paper I will argue that the two symbiotic narratives of "opening" and "globalization" make it possible for CCP leaders to present their policies, and in a wider perspective their rule, as an objective necessity. Opening is described as a voluntary and active policy initiated by the Chinese party-state, ${ }^{3}$ while globalization is referred to as an inevitable and objective economic trend. I call these two narratives symbiotic because they complement each other and compensate for each others' shortcomings. China's "opening” signals a reform-oriented leadership that dares to face the challenges of the world, while "globalization" explains why the state must be strong and unified in order to represent Chinese people's interests on the global scene. Together the two discourses pave the way for a representation of the CCP as a competent and rational manager of national interests in a competitive world where nation-states are still the main players.

The paper outlines five stages in the construction of these narratives. The first section looks at Deng Xiaoping's Reform and Opening policy from 1978, its historical background, and the understanding of China's role in the world on which it was based. During the 1980s China's increasing integration into the world generated fast economic growth and deep social change, but it also led to tensions between different perceptions of how China should open to the outside world, in particular in the political and cultural fields. These tensions are the topic of the second section, while the following part looks at the official discourse in the 1990s, when the term globalization became part of the Chinese political vocabulary. At this stage authoritative media established globalization as a challenging but inevitable trend that must be controlled by a strong state.

3 In China, the CCP and the state constitute formally separate hierarchies, but the Communist Party has de facto control over the state apparatus. Following what has become a convention in the academic literature, I use the expression "the party-state" or "the Party" to designate this phenomenon. 
Parallel to China's integration into the global economy the CCP embarked on a substantial internal transformation in order to be better prepared for any challenges that might occur with globalization. In the fourth section I look at this process through the lens of a number of speeches given in 2000 and 2001 by CCP general secretary Jiang Zemin. China joined the WTO in December 2001, so the speeches were given at a crucial moment for relations between China and the world, and they show how the parallel narratives of opening and globalization were basically in place by that time.

Finally, the Beijing Olympics in 2008 presented an occasion for the Chinese authorities to educate the public on the correct perception of and attitude to the increasing number of exchanges between Chinese and foreigners resulting from the opening/globalization process. Through the education campaigns discussed in the last section of the paper people in Beijing and around the country were taught how to interpret cultural differences in a way that matched the official narratives.

The focus will thus be on how China's leaders have told the story. One encouraging result of the Reform and Opening has been the creation of opportunities for the Chinese to express a wider variety of views. A broad range of interpretations and viewpoints on globalization can be found in Chinese academic journals, in newspaper columns, and on the internet, as convincingly demonstrated by several writers (Yu 2008, Knight 2008, Bhattacharya 2008, Garrett 2001). Neo-liberal, cultural conservative, and new-left voices can all be heard in this debate, so the discourse presented below is the dominant one, but it is not absolutely hegemonic.

\section{China's re-entry into the world}

The term globalization is often, and for good reasons, regarded with some scepticism. When did this process actually start, and how much has really changed? In contrast to most other people in the world, however, the Chinese can put a precise date on their re-entry onto the global scene: The announcement of the Reform and Opening policy in December 1978. China had, of course, had many contacts with the outside world before, even during the modern period. In the early $20^{\text {th }}$ century, for example, cities like Shanghai and Harbin were bustling international hubs with large foreign communities and intense international trade, 
and after the establishment of the People's Republic in 1949 technicians from the Soviet Union and other communist countries were a common sight in many Chinese cities. However, after the Sino-Soviet break in 1960 China became more isolated. The country's leaders perceived the major global powers as either capitalist/imperialist (the West) or revisionist/hegemonic (the Soviet block), and in this world inhabited by hostile forces self-reliance became the ideal. Except for diplomats there were very few foreigners in China, equally few Chinese were allowed to travel abroad, and the economy was geared to self-sufficiency. The official ideology talked about proletarian internationalism, but there was little in people's lives to indicate that there was a world outside China. Hardly any goods in the shops were of foreign origin and opportunities to access non-Chinese culture were limited, with Vietnamese and North Korean movies and a small selection of translated novels describing ordinary people's sufferings in the capitalist countries being the exception to these restrictions.

Today, only three decades later, China's international exchange of goods, capital, people, and ideas is massive. Even in remote villages young kids now know the names of football players in the Italian Serie $\mathrm{A}$, and their relatives are likely to work in faraway factories producing toys or sports gear for the global market. The specific effects of China's opening have converged with, and reinforced, the general trends we talk about as globalization, and the outcome has been a thorough and acutely felt transformation of social life.

Deng Xiaoping probably could not predict all these consequences of the Opening policy when he announced it, but when he gained political power in 1978 he realised that it was necessary to increase the flow of capital and technology from the outside world to turn China into the modernized and prosperous country he dreamed of. He was, however, confident that it would be possible to control the process he was initiating. With a famous phrase he compared the China of the Cultural Revolution era (1966-1976) to a house with closed doors and windows and a stuffy atmosphere. By 1978 the time had come to open the windows, he said, and let in some fresh air. Even if a few flies (read: Western bourgeois ideas) slipped in at the same time, it would not be a major problem. ${ }^{4}$ Deng was a firm supporter of opening China's economy

4 I have not been able to find out on which occasion Deng used this image, but it 
to the outside world, and comparing foreign ideological impact to a couple of flies rather than, say, a flood wave or an invasion was meant to calm down the many sceptics inside the CCP leadership, but he was probably also genuinely convinced that China would be able to filter the foreign inputs, use what was beneficial and keep the disagreeable elements out.

This view echoed the Chinese response to the Western challenge in the last half of the nineteenth century, when the country suffered numerous defeats at the hands of the Western powers and Japan, starting with the first Opium War (1840-1842). The moderate reformer Zhang Zhidong advanced in 1898 the slogan of "Chinese learning for the fundamental principles, Western learning for practical application" (zhongxue wei ti, xixue wei yong) as a strategy that could save China by reforming schools and industry without changing the country's Confucian values or the political system (Teng/Fairbank 1963: 164-166). Others suggested more drastic reforms, and after the fall of the Qing dynasty in 1911, and particularly with the May Fourth Movement starting in 1919, radical reformers also attacked the "fundamental principles" of traditional China. However, the ti-yong discourse of selectively borrowing "practical" elements from abroad without adopting wholesale the Western social, political or cultural institutions and values remained strong, and it was revived by the reformist Communist leaders during the Opening policy.

The Special Economic Zones that were established from 1980 onwards in a few carefully selected areas along the coast - such as Shenzhen close to Hong Kong and Xiamen across the strait from Taiwan were physical manifestations of this idea. They offered advantages to foreign investors, but they also controlled and encapsulated the foreign presence. During this early phase of the Opening, things foreign were certainly considered useful, but they were to be placed in designated mental and geographic zones whose borders could be controlled by the Chinese state.

From the very beginning of the Opening in 1978 China's reintegration into the world was thus a conscious strategic move by the country's

has consistently been attributed to him, both in China and abroad. The origin of other colourful expressions by Deng, such as 'It doesn't matter if the cat is black or white as long as it catches mice’ is, in fact, equally obscure. 
political leaders. The term used for the opening, kaifang, is a verb indicating a process of liberation from control and constraints. Kai means to open and fang is to set free, so the word signals a relaxation of the narrow state control over contacts with other countries that had characterized Mao's time. China is positioned as the active partner in this process, it deliberately decided to become kaifang, unlike the opening that was forced upon China after the Opium Wars. Besides referring to a more open attitude to the outside world, kaifang also had positive connotations of less political control over people's personal and economic life, and a livelier and more relaxed cultural atmosphere.

\section{Opening or "wholesale Westernization"?}

As a result of the opening, imported goods and foreign ideas, lifestyles, and popular culture became increasingly popular among Chinese citizens, particularly students and other young urbanites. Throughout the 1980s it became evident that Deng's "flies through the open window" metaphor no longer sufficed to describe the growing tension between representations of "Chinese" and "foreign". A six part TV documentary Deathsong of the River (Heshang) from 1988 presented a radical reinterpretation of this theme in Chinese history, when it contrasted an isolated and stagnating China, symbolized by the Yellow River, with an open and progressive Western culture represented by the blue sea. According to the critical young intellectuals behind this TV series the fear of foreign influence is something uniquely Chinese:

The greatest difficulty of reform lies perhaps in that we are always worrying: “Are the Chinese people still Chinese?” We seem not to realize that throughout the past two or three centuries in the West, no matter whether it was the Renaissance, the Reformation, or the Enlightenment movement, Western Europeans at least never worried whether after reform they would still be Italian or German or French. Only in China is this the greatest taboo of all (Su/Wang 1991: 212).

The script writers identified China's isolation from the outside world as the main cause of its historical decline and linked its autocratic political system and low level of economic development to its Confucian tradition. The "true spirit of science" and "a true democratic consciousness" would never grow out of the "dirt-yellow land" (p. 212), so in order to regain its vitality the Yellow River "must eliminate its fear of the sea" 
(p. 268) and finally flow into the ocean. The message was thus that China should absorb much more than just investments and advanced technology from the West, it was the entire national spirit or mentality that should be changed.

Deathsong of the River drew enormous attention both in China and abroad, and it sparked off a heated debate about China's relations with the West. It was accused of advocating "wholesale Westernization" (quanpan xihua) (Su/Wang 1991: 312), a term which was first promoted by the liberal thinker Hu Shi in 1929 but later has been used to criticize an unpatriotic awe of the West. Su Xiaokang, the most prominent of the script writers later played a major role in the Beijing uprising of 1989, and after the violent suppression of the democracy movement he was placed high on the authorities' list of "wanted criminals." His vision of how far China's opening to the West could go had overstepped the limits of what the post-Tiananmen CCP leadership could tolerate, and he had to flee to the USA.

The demonstrations on Tiananmen Square and their subsequent suppression marked a turning point for China's Opening policy. The factors leading to the demonstrations and the course of events are complex and well documented, and the foreign/Chinese dichotomy was only one of several themes in the conflict. ${ }^{5}$ However, the short-term effects of June 1989 on the Opening policy were very serious. The Chinese leadership was met with universal criticism from the West and became a global symbol of ossified tyranny, and inside China violent suppression was followed by ideological campaigns that linked pro-democracy demonstrators with "hostile forces" threatening China from abroad. The increasing hostility between China and the West, particularly the USA, "left a legacy of suspicion that fed into the very different intellectual atmosphere that would emerge in the 1990s" (Fewsmith 1999: 42-43).

The economic opening was only briefly blocked, however. In January 1992 Deng Xiaoping visited two of the first special economic zones, both successful symbols of the Reform and Opening policy, and confirmed his continued support for the idea behind them. In spite of resistance from some CCP leaders China thus avoided a return to the closeddoor policy of the pre-1978 period, and the process of ever closer inte-

5 Among the many insightful treatments of these events are Saich 1990 and Brook 1992. 
gration into global capitalism could continue unabated. In contrast, the intellectual climate never returned to the honeymoon days of the 1980s when many Chinese had a highly idealized perception of the West. In the 1990s the general tone in the public media became more sceptical towards the Western powers and the relevance of Western ideas for China. Patriotic education was stressed in schools, and many intellectuals expressed strong nationalist sentiments (Gries 2004, Hughes 2006). The CCP did not intend to let the Opening herald the closing stage of its own rule.

\section{Globalization as a double-edged sword}

From the middle of the 1990s the discourse of opening was supplemented by one of globalization. In the Chinese word for globalization, quanqiuhua, quanqiu means the globe, or global, and -hua is a suffix similar to -ization or -ification in English, designating a change towards the state specified by the first part of the word. Unlike the process of kaifang, globalization is something that China and the rest of the world is exposed to, not the result of political choice.

This section looks at how the term was used in the People's Daily (Renmin ribao) particularly in the 1990s when the concept was defined. The Chinese press is much more pluralistic now than during Mao's time, and newspapers such as the World Economic Herald (Shijie jingji daobao) from Shanghai and Guangzhou's Southern Weekend (Nanfang zhoumo) and Southern Metropolis (Nanfang dushibao) have, at different times, demonstrated that it is possible to carve out space for critical journalism in spite of the censorship. The People's Daily, however, still functions as the official mouthpiece of the Party. This does not mean that every single article can be read as authoritative. Columnists and commentators are allowed to express divergent views on many questions, including the causes and effects of globalization, but the general trend in the paper's coverage of major issues still expresses the views of the majority fraction in the Chinese leadership. A closer look at how globalization has been discussed in this newspaper can therefore show which understanding of the term the party-state has been promoting.

The term first appeared in the People's Daily as early as 1986, but it was rarely used during Deng Xiaoping's time in power, and then only in connection with trends and events abroad, typically reports on a cri- 
sis in the global financial markets or in a Japanese or US multinational company. Up to 1996 globalization was still seen as something going on "out there" which had only an indirect impact on China. From around 1996, however, China was increasingly presented as an integrated part of the global economy. In 1996 Li Tieying who was then chairman of the powerful State Commission for Restructuring the Economy and member of the Politburo described very straightforwardly the role of China in the global division of labour:

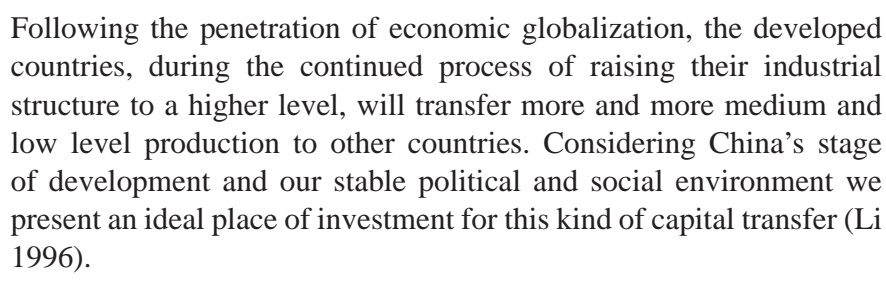

Li evidently pictured China in the low end of the capitalist food chain, offering cheap labour and social stability to foreign companies, but he was very optimistic in his assessment of globalization. His main conclusion was that China was entering the world at full speed, and that this trend would be to the mutual benefit of China and the world, because China was not just a producer of cheap goods but also presented a promising market for foreign companies.

During the Asian financial crisis that started in 1997 the tone in the Chinese media became more cautious, and since that time the People's Daily has repeatedly used the metaphor of a double-edged sword to describe the positive and negative potentials of globalization. It is said to offer enormous possibilities for China and other developing countries, but it can also lead to further polarization between rich and poor, and to a marginalization of those less developed countries that are not sufficiently competitive. The problematic aspects of globalization are normally presented as common conditions for all developing countries, and while it is acknowledged that some countries in Africa and other places are more likely than China to succumb under the pressure of the market forces, the People's Daily downplays the competition between developing countries for foreign investments.

From the late 1990s economic globalization was consistently presented as an objective fact, a "historic tidal wave", a turn of the "wheel of history." In spite of all dangers involved in the new global process- 
es, ignoring them was not an option. Instead China must try to make the best of the situation. As one researcher expressed it in the newspaper in 1998, some rules in the international economic game were fair enough and beneficial to China, so China would obey them. Other rules were also fair but did not benefit China, and in those cases China would slowly have to adapt to them. Finally, some rules were unreasonable and harmful to China and other developing countries, so China should resist them and try to change them (Gu Yuanyang 1998). The wheel of history could not be stopped, but it could be pushed in a direction that would benefit China.

As can be seen from Table 1, the People's Daily's use of the term globalization peaked in 2001, when China joined the WTO in December. As many as 933 articles mentioned the word that year, more than ever before or after.

\begin{tabular}{|l|l|l|l|}
\hline 1985 & 0 & 1997 & 135 \\
\hline 1986 & 1 & 1998 & 349 \\
\hline 1987 & 3 & 1999 & 429 \\
\hline 1988 & 5 & 2000 & 823 \\
\hline 1989 & 6 & 2001 & 933 \\
\hline 1990 & 13 & 2002 & 781 \\
\hline 1991 & 8 & 2003 & 692 \\
\hline 1992 & 7 & 2004 & 619 \\
\hline 1993 & 9 & 2005 & 696 \\
\hline 1994 & 16 & 2006 & 638 \\
\hline 1995 & 50 & 2007 & 645 \\
\hline 1996 & 86 & 2008 & 372 \\
\hline
\end{tabular}

Figure 1. Number of articles in the People's Daily mentioning the word globalization $^{6}$

Joining the WTO could have proved problematic for many Chinese, particularly farmers who were not necessarily able to compete on the world market, so the media worked intensely on shaping a favourable

6 I have used the search term globalization (quanqiuhua) in the full text of all articles in the Chinese electronic version of the People's Daily: Renmin Ribao dianziban 1946-2008. 
public opinion about the topic. Few farmers read the People's Daily but the local officials, who constitute its key audience, had to be well prepared for any dissatisfaction that might occur. The main impression left by the media was that globalization was a process full of dangers, and that only strong and competent nation-states, such as China, could tame the transnational companies and other global actors.

In Marxist terms the CCP justified its embrace of globalization and global capitalism by emphasizing the development of the productive forces as the determining power in history while ignoring the other crucial element in Marxist development theory: Class struggle (Knight 2008: 89-117). According to this legitimizing narrative the main task of the CCP was to develop the productive forces by attracting foreign investments and technology. Seeing globalization as a victory of capitalism was a mistake, the Chinese were told. On the contrary, globalization would sharpen the inherent contradictions in capitalist states and thus strengthen the socialist world in the long run. In Knight's (2008: 108) words:

The struggle is thus portrayed as an economic struggle between na-
tions of different ideological and political persuasions, a struggle that
will result in the economic decline of the capitalist nations and rise and
eventual victory of the socialist nations.

While China's ever closer integration into the global economy was presented almost as a law of nature, the People's Daily showed a much more sceptical attitude towards other aspects of globalization. In the article mentioned above, Gu Yuanyang (1998) admitted that globalization was not just about economy, but the non-economic examples he mentioned were all about negative trends and problems that must be solved through international cooperation, such as pollution, international crime, and drugs. Other articles mentioned AIDS and Mad Cow Disease as typical outcomes of globalization. When political globalization was mentioned it was often accompanied by a warning against using the concept as a cover for promoting Western values and interests, like when the USA allegedly used globalization as an argument for its intervention in Yugoslavia in 1999 (Huang 1999), or when Western lawyers argued for more supranational legislation (Shen 1999).

In the cultural field, the People's Daily prefers the term diversification (duoyanghua) to globalization. Cultural diversity should be pro- 
tected and Americanization avoided at all costs. In this spirit the People's Daily has reported positively on European resistance to cultural homogenization based on US culture and on events that show how nations and people all over the world turn against American cultural invasion. The image of the doubled-edged sword also leaves room for sympathy with globalization sceptics outside China. Instead of denouncing all opposition as reactionary a commentator from the prestigious Tsinghua University explained that "anti-globalization does not mean opposition to globalization as such but to all the different problems that globalization brings along." What people around the world are opposed to is the American neo-liberal version of globalization with its increasing social disparities, but this is only one of several paths that globalization may follow (Pang 2001). However, the official press does not give much space to Chinese anti-globalization voices.

\section{How globalization changed the CCP}

By the turn of the $21^{\text {st }}$ century the globalization narrative outlined above was firmly in place, but that did not mean that a completely unified Chinese leadership subscribed to it. China's accession to the WTO was a disputed move, and in early $2000 \mathrm{Li}$ Peng, chairman of the National People's Congress, attacked the market oriented policies of Party secretary Jiang Zemin and Premier Zhu Rongji (Fewsmith 2001: 228-229). But Jiang and Zhu had accepted globalization as an economic reality and decided to have a proactive attitude towards the many new challenges. China's entry into the WTO in 2001 was perhaps the most significant manifestation of the route they chose, but the top leaders' understanding of the world had consequences far beyond the fields of international trade. Parallel to China's integration into the global economy the CCP embarked on a substantial transformation of the party's guiding ideology, recruitment patterns, and ruling techniques in order to adjust itself to the "new historical conditions" (Jiang 2001: 1).

These transformations were announced by Jiang Zemin, who was general secretary of the CCP from 1989 to 2002 and China's president from 1993 to 2003. Towards the end of his time in office, Jiang introduced the theory of "the three representations" (sange daibiao), which defined the Party's role for the 21st century. According to Jiang (2001: 2 ), the CCP should represent "the requirements of the development of 
China's advanced productive forces, the orientation of the development of China's advanced culture, and the fundamental interests of the overwhelming majority of the people in China."

In order to establish the status of his theory as part of CCP's ideological orthodoxy Jiang delivered a number of speeches between February 2000 and July 2001. In August 2001 excerpts from twelve of these speeches were published in a volume entitled On "The Three Representations" (Jiang 2001). Party members were supposed to study this volume in order to grasp Jiang's theory. I will treat the twelve speeches as one text addressing all CCP members, regardless of the specific time and audience of each speech. Read as a whole the book sums up Jiang's position and shows how the CCP leadership wanted party members to perceive the global situation and its implications for China just after the turn of the $21^{\text {st }}$ century.

Jiang made it clear that the Reform and Opening policy had created a new class structure with several social groups that did not exist in the PRC in pre-reform days, such as private entrepreneurs and traders, individual farmers, and high-salaried employees in foreign enterprises. This increased social diversification required the CCP to understand its own role in a new way (p. 8-9). At the same time ideological control had been made much more difficult by the rapid spread of unauthorized information which was one result of the Reform and Opening: "The information that cadres and masses receive is very rich but also of uneven quality, and their ideas are extremely lively, so it is not so easy to unify their thinking” (p. 53).

Also the international environment had changed. Socialism had suffered a huge setback after the fall of communist rule in Eastern Europe and the disintegration of the Soviet Union, and some CCP members had subsequently been hit by a "crisis of faith" (p. 55). The collapse of socialism in the Soviet block had to a large extent been caused by consistent Western propaganda, and China was the next target:

China is now the world's largest socialist country, and it is continuously developing and getting richer and stronger every day. Hostile forces in the West are speeding up their political strategy of "westernizing" and "splitting" our country by all means and in all possible ways, attempting to subvert the CCP leadership and China's socialist system. They are certainly not going to change these political plots (p. 61). 
As part of its efforts to keep China down, the West would use such issues as democracy, human rights, and the Taiwan and Tibet problems, and Jiang predicted that the conflict would be "long and complicated” (pp. 61-62). However, Western hostility should not make China close its doors. The CCP should not repeat the mistakes of the Qing dynasty (1644-1911), which had once been the strongest economy in the world but - with the well-known disastrous consequences for China - had complacently closed its borders in the $19^{\text {th }}$ century and thereby missed the industrial revolution and its many technological innovations (pp. 36-37). So the double-edged sword should be met with a balanced strategy: While China "should stick to the policy of Reform and Opening and strengthen our economic and cultural exchange with the outside world, we should at the same time pay close attention to guarding against infiltration and subversion from hostile forces” (p. 62).

Jiang's analysis goes well beyond the Cold War image of a zero-sum battle between socialism and capitalism. In a globalized world the key to victory does not primarily lie in military force but in technological innovation, according to Jiang. "The present and future global competition is fundamentally a competition for qualified people (rencai)" (p. 31 ), and as "[t]he developed countries fight to grasp qualified people all over the globe" (p. 68), China must make sure to get its share. These "qualified people" can make China a winner in the global competition and they constitute the link between Jiang's analysis of China's international position, and his controversial plan for the CCP: The communist party should start recruiting members from the emerging economic elite. This plan was presented in its most mature version in the last speech included in On "The Three Representations", delivered on 1 July 2001 at the $80^{\text {th }}$ anniversary celebrations of the founding of the CCP (pp. 143-185). Among the new social strata of private businesspeople and highly skilled technical and managerial personnel in both Chinese and foreign-owned enterprises, there were many who through hard and honest work had "made contributions to the production forces in socialist society...” (p. 169). As long as they were loyal to the Party's principles, such "excellent elements" (youxiu fenzi) should, according to Jiang, be recruited into the CCP. This recruitment policy would strengthen social cohesion and strengthen the CCP's position in Chinese society (p. 170). 
The inclusion of the new social strata of private capitalists and whitecollar employees was, of course, controversial in a self-proclaimed proletarian party such as the CCP, but Jiang had little choice, as he could see that the private sector was growing rapidly. By 2005 it would produce well over half of China's GDP and an overwhelming share of its exports and also create most of the new jobs (OECD 2005: 1). This trend was evident already at the turn of the century. Besides being the main motors in China's economic growth, however, the private entrepreneurs also represented a potential political challenge to CCP rule. Jiang's solution to this problem was to ensure that the party-state would be solidly embedded in society, particularly in relation to the new economic elite in the private enterprises. As Evans (1995: 248) has shown, in order to function properly developmental states, of which China is one variety, "must be immersed in a dense network of ties that bind them to societal allies with transformational goals". By integrating the economic elite the CCP tried to maintain its dominant position as the centre of such networks.

Once the alliance between China's political and economic elites was in place the party-state could set to work on making Chinese enterprises more competitive. In this way the party-state behaved as a "competition state” in Cerny's sense:

\footnotetext{
Rather than attempt to take certain economic activities out of the market, to "decommodify" them as the welfare state [and to an even larger extent the socialist state, ST] was organized to do, the competition state has pursued increased marketization in order to make economic activities located within the national territory... more competitive in international and transnational terms” (Cerny 1997: 259).
}

The discourse on globalization as an inevitable and irreversible trend, which implied intense economic competition between nation-states had paved the way for a transformation of the CCP into a more elitist party. Translated into practical policy this meant that members of the economic elite were recruited to the party and given seats in political consultative conferences and people's congresses, which have limited power, but represent an opportunity for business people to establish useful contacts to officials and maybe affect local decisions. ${ }^{7}$ To the CCP the pres-

7 Political consultative conferences (Zhengxie) are advisory bodies through which influential members of society can be included in the political process. Their actual 
ence of successful entrepreneurs lends legitimacy to the political institutions controlled by the Party.

Even more important links between the party-state and the new economic elite are the corporatist business associations that have been established all over China. These associations monopolize the organization of business interests, facilitate communication between state and business and make it possible for the state to supervise and control enterprises. But they are first of all arenas for building networks that tie the economic and political elites closer to each other. Sociologist David Wank (1999) has analyzed how such networks operate in the prosperous city of Xiamen in Fujian province. While we would normally expect market oriented reforms to liberate business from state control, China has rather seen the planned economy being replaced by networks of businesspeople and local officials. The two groups need each other and live in a "symbiotic clientelism" (Wank 1999: 231) to their mutual economic and political advantage.

The close relations between businessmen and officials are also reflected in the fact that the political attitudes of the two groups are strikingly similar. In the words of Bruce Dickson (2007: 827), who has done several surveys on the political attitudes and values of officials and businessmen: "Rather than promote democratic governance, China's capitalists have a stake in preserving the political system that has allowed them to prosper, and they are among the Party's most important bases of support.” Dickson's surveys even show that businesspeople are more likely than officials to think that pluralism can lead to political chaos (Dickson 2007: 851).

Another potential threat to the CCP's control over the globalization process could be China's workers. While the economic elite has a material interest in preserving the status quo, the workers have lost many of their former privileges since the 1990s, such as job security and the provision of cheap housing. A cheap and obedient workforce has been one of China's strong cards in the global competition for foreign invest-

power is very limited, but they can criticize aspects of the party-state's work and offer suggestions. People's congresses (Renda) at the national, provincial, county, and township levels constitute China's parliamentary system. The National People's Congress is China's legislative body. People's congresses have recently gained some influence in China as supervisors of local governments and platforms for moderate criticism but they are still controlled by the party-state. 
ments, and the Chinese labour unions are not geared to defend workers' interests in a market economy. However, although there have been many isolated strikes and other types of industrial action, there is little evidence that the workers blame the state or the globalization process for their problems. Interviews indicate that most workers accept the competition of global capitalism almost like a law of nature and explain their problems on the job market with their own personal shortcomings such as lack of relevant skills (Blecher 2002). In this sense they have adapted to the liberalist ideology of a globalized labour market.

Jiang's suggestions for reforms of the CCP have far-reaching implications for China's social and political institutions, and so do the privatization of the economy and other reforms that have been implemented since the early 1990's. However, he cannot be accused of selling out to foreigners or of being a naive supporter of globalization, because he specifically warns against the "hostile forces" of the West. On the opposite front he distances himself from the closed and xenophobic attitude of the past (and, implicitly, of rival leaders such as Li Peng) by showing how the "development of the most advanced productive forces" depends on China's integration into the global economy. This double track discourse of opening and globalization is more than just a repetition of the ti-yong formula of the Qing period (making use of Western technology while preserving the Chinese essence) or even of the "flies through the window" attitude of the early phase of the opening policy. It integrates a comprehensive opening to the world with one crucial "essence" that is still zealously guarded, and which is presented in the speeches as a precondition for securing China's competitive edge in the global struggle for economic advantages: The party-state's monopoly on political power.

\section{The Beijing Olympics and the pedagogy of globalization}

In the years that have passed since Jiang made his speeches, China's approach to globalization has developed further. The most significant trend is probably a growing self-assurance. The government has implemented a "going out" policy, which means that Chinese companies now invest massively abroad while Chinese brands are being much more actively developed and promoted around the world. China has also turned proactive in the cultural field with the establishment of Confucius In- 
stitutes abroad, much like the German Goethe Institutes or the French Alliance Francaise. The Confucius Institutes are expected to "promote a better understanding of the Chinese language and culture among the people of the world; develop friendly relationships between China and other countries; accelerate the development of multiculturalism at the international level; and help bring about global peace and harmony."

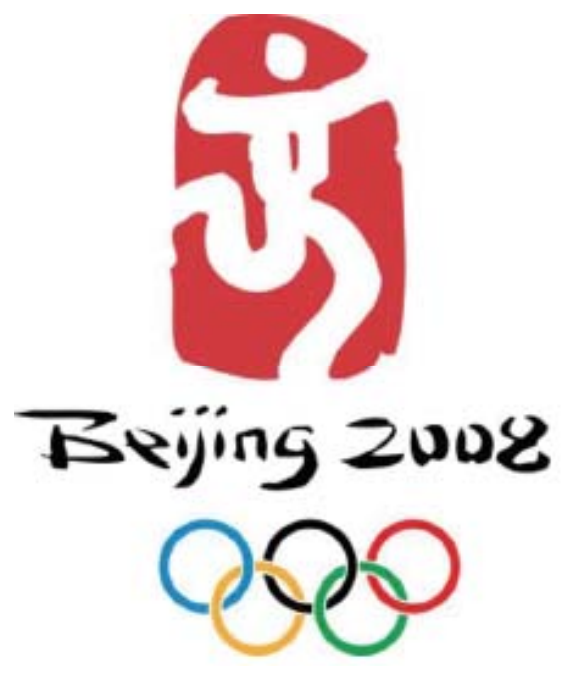

The Beijing Olympics in 2008 presented a perfect opportunity for the party-state to demonstrate to the world and not least to its home audience that China was now a major power and a respected member of the international community. The slogan chosen for the Games, One World, One Dream, (Tong yige shijie, tong yige mengxiang) signalled shared ideals and aspirations across borders, but it was also important that the Games had "Chinese characteristics". This Chineseness was, for example, reflected in the logo, which resembled a person in motion on a red background but at the same time could be seen as a symbol of China's cultural heritage. To a Chinese audience the logo looked like an ancient Chinese seal engraved with a character that resembled both jing (京), meaning 'capital', the last character in the name of Beijing, and

8 Quoted from Confucius Institute Online, http://www.confuciusinstitute.net/blogs/ po/hq/posts/229 (accessed 10 February, 2009). 
wen (文) which in itself means 'script' and is part of words like culture (wenhua), civilization (wenming), and literature (wenxue). The opening ceremony of the Games, directed by China's most internationally acclaimed film director Zhang Yimou, likewise featured Chinese history and traditional culture very prominently (Barmé 2009). ${ }^{9}$

The prelude to the Games in the spring of 2008 indicated the problems that might be triggered when China became the focus of global attention. China was attacked in the Western media for, among several other things, its role in Darfur and Tibet, its lack of human rights, and its environmental problems, and the Olympic torch relay was disrupted in Paris and other Western cities. In reply the Chinese internet was soon filled with virulent verbal denunciations of particularly Japan, the USA and France, and in April and May 2008 there were demonstrations against Carrefour in several Chinese towns after the French supermarket chain had been accused by Chinese Internet users of supporting the Dalai Lama (Xinhua 2008).

Confrontations between foreigners and Chinese were detrimental to China's ambitions for the Olympics, and the party-state had worked hard to prevent them. It had been decided early on that the citizens of Beijing should learn to be worthy ambassadors of China and leave the foreign guests with a favourable impression. The city's taxi drivers attended English classes, and there were campaigns to stop people from spitting in the street and jumping queues. As a central part of this campaign a set of textbooks in 13 volumes addressing different audiences was published in August 2006, two years prior to the event (Beijing Aoyunhui 2006a). It was edited by a committee of specialists from several official bodies involved in the games with the help of researchers from some of China's most renowned universities. Two of these textbooks addressed two groups who would come into direct contact with foreigners: Volunteers (Beijing Aoyunhui 2006b) and employees in the service sector (Beijing Aoyunhui 2006c). The ideal relationship between Chinese and foreigners outlined in these volumes mirror and reinforce the image of China's relations to the world which had been shaped over the years by the narratives of opening and globalization.

9 A recent themed issue of The China Quarterly (no. 197, March 2009) contains four illuminating articles on the Beijing Olympics by Anne-Marie Brady, Kevin Latham, Susan Brownell, and Geremie R Barmé. 
The volume for service personnel places the Olympics in the larger context of China's traumatic past. A chapter titled "From the 'Sick Man of Asia' to a Rising Giant” (Beijing Aoyunhui 2006c: 26-28) says that " ... our one hundred years of relations with the Olympic movement is a distillate of the entire $20^{\text {th }}$ century history of China” (p. 26). Therefore, the Olympics are not just about sports. The Games should demonstrate for everyone China's rise in the world: "Let likewise politicians from all nations stand under the banner of Olympic peace and contemplate the establishment of a new world order, and let shrewd celebrities from the business world seek out unlimited business opportunities in an increasingly globalized market...” (p. 44).

The Chinese who come into direct contact with foreigners represent much more than just themselves: "Quite often we represent our workplace, our profession, and we also represent our city, people and nation" (p. 147). In this situation, it is crucial that cultural differences do not spoil the harmony between Chinese and foreigners. The textbook mentions some typical examples of misunderstandings rooted in cultural differences. A foreigner will open a gift in front of the giver, although this is considered impolite in China. An elderly foreign man cannot accept that a young Chinese woman carries his bag, although she just wants to express respect for his senior status. A Chinese host orders too many dishes to show his hospitality, but his foreign guests see this as a waste of food (p. 146-147). The volunteers' textbook has a section on taboos, which likewise takes for granted that individuals represent their cultures, and that these cultures are defined either by nation-state or by religion. The volunteers learn, for example, that Mexicans and Indians do not like the colour white, while Ethiopians and Brazilians have an aversion to yellow, and Belgians and Iraqis avoid blue. Christians consider Friday an inauspicious day, Muslims do not eat pork, and Hindus avoid beef (Beijing Aoyunhui 2006b: 125-126).

No deeper conflicts of interests are at stake in any of the examples taken up by the textbooks, and problems can be solved if the service personnel know and respect the relevant cultural differences. However, respecting other cultures does not mean that these cultures are in any way superior to the Chinese:

In fact, for historical, economic and cultural reasons there are some people in our present society who easily become too enthusiastic and 


\begin{abstract}
"humble" towards foreign guests from developed countries, while feeling superior in front of their own compatriots. However, a truly well-bred Westerner will always think that a person who looks down upon his fellow countrymen is not worthy of respect! So during the Beijing Olympics we must pay special attention to respecting both ourselves and the guests (Beijing Aoyunhui 2006c: 147-148).
\end{abstract}

The textbooks are certainly not aggressively nationalistic, to the contrary, they repeatedly stress that foreigners should be greeted with hospitality and respect. At the same time they underpin an understanding of global relations that fits perfectly into the state-centred narratives of opening and globalization. Individuals represent their nation-state and their values and habits are defined by its culture. Conflicts between such national cultures can be solved through dialogue and a better understanding of each other's background, but this should not lead to the waning of cultural difference. The purpose of the dialogue is rather to create a space for each nation to exhibit its cultural characteristics without interference from others.

While preparing Chinese citizens well for their role as Olympic hosts this discourse is not of much help when fundamentally different ideological and political positions clash as happened in the run up to the Olympics. In conflicts over Tibet, Taiwan, human rights, and several other issues foreign criticism of Chinese state policies are presented in the Chinese media as interference in internal Chinese affairs. As expressed by Hu Jintao in the quotation that opened this paper, "Chinese affairs must be handled by Chinese people in a Chinese way." In a comment that was probably not meant for an international audience Xi Jinping, Hu Jintao's most likely successor, expressed the same point more bluntly in February 2009: "There are some well-fed foreigners with nothing better to do who point their fingers at our affairs. First of all, China does not export revolution; second, we do not export poverty and hunger; and third, we do not cause you any trouble. So what can they say?"10 To

$10 \mathrm{Xi}$ made this remark at a meeting with Mexicans of Chinese descent. A video of the occasion was circulated widely on the internet. For the quotation in print and a very positive Chinese comment on Xi's viewpoint see [online] http://news.sina.com/ ch/xinhuanet/102-101-101-102/2009-02-12/19283633091.html (accessed 13 February 2009). 
$\mathrm{Hu}$ and $\mathrm{Xi}$, of course, the CCP represents the Chinese people and can speak on its behalf.

\section{Conclusion}

The simultaneity of the international spread of the globalization discourse with China's own policy of Reform and Opening led to a positive and proactive Chinese approach to globalization. A strong state was seen as a prerequisite for making China a winner in the global competition, and to guarantee sustained Party rule under the new economic conditions Jiang Zemin led a transformation of the CCP, which tied the economic elite more closely to the Party. It is still too early to say what the long-term international and domestic consequences of this transformation will be, but for the moment it has been successful. Even among industrial workers and other underprivileged social groups the symbiotic discourses of opening and globalization promoted an understanding of China's economic growth as a result of the opening policy, while social problems, poor work conditions, and increasing inequality can be blamed on objective mechanisms governing the global capitalist market.

China's engagement with the world is not only economic, but also cultural and political. In these fields CCP leaders have used the term globalization only reluctantly and established a discourse of cultural and political diversity in its place. In encounters with foreigners, like those that took place before and during the Beijing Olympics, Chinese people are seen as representing their nation, and tensions are reduced to cultural differences which should be accepted as natural. In this construction of the global there is little room for foreign criticism of China.

\section{References}

Barmé, Geremie R. 2009: China’s Flat Earth: History and 8 August 2008. In China Quarterly 197, 64-86.

Beijing Aoyunhui 2006a: Beijing Aoyunhui tongyong peixun xilie jiaocai (A set of general training materials for the Beijing Olympics). Beijing: several publishing houses.

Beijing Aoyunhui 2006b: Beijing Aoyunhui zhiyuanzhe duben (Beijing Olympics Reader for Volunteers), Beijing: Zhongguo renmin daxue chubanshe. 
Beijing Aoyunhui 2006c: Beijing Aoyunhui chuangkou hangye yuangong duben (Beijing Olympics Reader for Service Sector Employees). Beijing: Beijing chubanshe.

Bhattacharya, Abanti 2008: Interpreting the Chinese Discourse on State in the Era of Globalization. In Strategic Analysis 32:4, 583-603.

Blecher, Marc J. 2002: Hegemony and Workers' Politics in China. In China Quarterly 170, 283-303.

Brook, Timothy 1992: Quelling the People. The Military Suppression of the Beijing Democracy Movement. Oxford: Oxford University Press.

Cerny, Philip G. 1997: Paradoxes of the Competition State: The Dynamics of Political Globalization. In Government and Opposition, 32:2, 251-274.

Dickson, Bruce J. 2007: Integrating Wealth and Power in China: The Communist Party's Embrace of the Private Sector.” In China Quarterly 192, 827-854.

Evans, Peter 1995: Embedded Autonomy. States and Industrial Transformation. Princeton: Princeton University Press.

Fewsmith, Joseph 2001: China since Tiananmen. The Politics of Transition. Cambridge: Cambridge University Press.

Garrett, Banning 2001: China Faces, Debates the Contradictions of Globalization. In Asian Survey 41:3, 409-427.

Gries, Peter Hays 2004: China’s New Nationalism. Pride, Politics and Diplomacy. Berkeley \& London: University of California Press.

Gu Yuanyang 1998: Jingji quanqiuhua yu “youxi guize” (Economic globalization and the "rules of the game”). In People's Daily, 6 June.

Hu Jintao 2008: Hu Jintao zai jinian dang de shiyi jie san zhong quanhui zhaokai 30 zhounian dahuishang de jianghua (Hu Jintao's speech at a meeting celebrating the 30th anniversary of the 3rd plenum of the 11th Party Congress). From People's Daily Online, Dec 18, 2008 [online]. http://politics.people.com.cn/GB/1024/8544663. html (accessed 15.01.2009).

Huang Nansen 1999: "Rendaozhuyi ganshe” de shizhi (On the true nature of "humanitarian intervention”). In People's Daily, 3 June.

Hughes, Christopher R. 2006: Chinese Nationalism in the Global Era, Abingdon: Routledge, 2006.

Jiang Zemin 2001: Lun “sange daibiao” (On “The three representations”). Beijing: Zhongyang wenxian chubanshe.

Knight, Nick 2008: Imagining Globalisation in China. Debates on Ideology, Politics and Culture. Cheltenham: Edward Elgar.

Li Tieying 1996: Zouxiang 21 shiji de Zhongguo yu shijie jingji de fazhan (China on its way to the 21st century and global economic development). In People's Daily, 15 Nov.

OECD (2005) Policy Brief: Economic Survey of China, 2005 [online]. http://www. oecd.org/dataoecd/10/25/35294862.pdf 
Pang Zhongying 2001: Fan-quanqiuhua bu shi fandui quanqiuhua benshen, er shi fandui quanqiuhua dailaide gezhong wenti (Anti-globalization does not mean opposition to globalization as such but to all the different problems that globalization brings along). In People's Daily, 17 Aug.

Saich, Tony, ed. 1990: The Chinese People’s Movement. Perspectives on Spring 1989. Armonk, New York: M.E. Sharpe.

Shen Zongling 1999: "Ping 'falü quanqiuhua' lilun" (Comment on the theory of "legal globalization”. In People's Daily, 11 Dec.

Su Xiaokang/Wang Luxiang 1991: Deathsong of the River. A Reader's Guide to the Chinese TV Series Heshang. Ithaca, N.Y.: Cornell University East Asia Program.

Teng, Ssu-Yu/John K. Fairbank 1963 [1954]: China's Response to the West. A Documentary Survey 1839-1923, New York: Atheneum.

Wank, David L. 1999: Commodifying Communism. Business, Trust, and Politics in a Chinese City, Cambridge: Cambridge University Press.

Xinhua News Agency 2008: Protests erupt at Carrefour outlets in China, posted on May 1 at [online] http://news.xinhuanet.com/english/2008-05/01/content_8085889. htm (accessed 08.02.2009).

Yu Keping 2008: The Developmental Logic of Chinese Culture under Modernization and Globalization. In boundary 2, 35:2, 157-182. 